\title{
Homalodisca coagulata (Hemiptera, Cicadellidae) Transmission of Xylella fastidiosa to Almond
}

\author{
R. P. P. Almeida, Department of Plant and Environmental Protection Sciences, University of Hawaii at Manoa, \\ Honolulu 96822; and A. H. Purcell, Department of Environmental Science, Policy, and Management, University of \\ California, Berkeley 94720
}

\begin{abstract}
Almeida, R. P. P., and Purcell, A. H. 2003. Homalodisca coagulata (Hemiptera, Cicadellidae) transmission of Xylella fastidiosa to almond. Plant Dis. 87:1255-1259.

Almond leaf scorch (ALS) is caused by the bacterium Xylella fastidiosa, transmitted by sharpshooter leafhoppers and spittlebugs. The recent invasion of a X. fastidiosa vector, Homalodisca coagulata (Hemiptera, Cicadellidae), into California may have major consequences to the spread of ALS because this insect feeds readily on trees, including stone fruit species. We found that, under laboratory conditions, $H$. coagulata acquired $X$. fastidiosa from symptomatic almond plants with low efficiency relative to grape (3.3 to $10 \%$ per individual per day). Inoculation efficiency also was low, approximately $4 \%$ per insect per day. $H$. coagulata inoculated 1 -yearold woody tissues of almond plants at similar rates as green shoots. $H$. coagulata transmitted two X. fastidiosa grape strains from grape source plants to grape and almond. We also observed $X$. fastidiosa transmission to dormant almond plants. $X$. fastidiosa populations in the petioles of field-collected symptomatic almond leaves were not higher than $10^{7} \mathrm{CFU} / \mathrm{g}$ of tissue, suggesting that low bacterial populations within almond are partially responsible for the lower acquisition rates observed from diseased almond compared with diseased grape, which are usually within the range of $10^{8}$ to $10^{9} \mathrm{CFU} / \mathrm{g}$. The relevance of our findings to ALS epidemiology, considering $H$. coagulata as a vector, is discussed.
\end{abstract}

Additional keywords: glassy-winged sharpshooter, Pierce's disease, Prunus, xylem

Almond (Prunus amygdalus) leaf scorch (ALS) is caused by the xylem-limited bacterium Xylella fastidiosa (5), which is disseminated by sharpshooter leafhoppers (Hemiptera, Cicadellidae) and spittlebugs (Hemiptera, Cercopidae) (22). Moller et al. (17) first described the disease in 1974 in almond orchards in California, although it probably has been present in the state at least since the 1950s. Based on symptoms observed, ALS also may be present in India (7), but this needs confirmation. The sporadic occurrence has not made this disease a major threat to California's almond industry (19).

Sharpshooters and a spittlebug are experimental vectors of $X$. fastidiosa to almond (19). However, there was no ecological or epidemiological evidence to associate either species as a major vector in the field. The common observations that the incidence of Pierce's disease (PD) in grapevines diminished with distance from bordering alfalfa fields in the 1930s led to

Corresponding author: A. H. Purcell

E-mail: purcell@nature.berkeley.edu

This research was funded by the Almond Board of California.

Accepted for publication 22 May 2003.

Publication no. D-2003-0813-01R

(c) 2003 The American Phytopathological Society discoveries that alfalfa dwarf disease was caused by the same pathogen that caused PD (9). This led to the identity of the insect vectors for both diseases. However, little is known about ALS epidemiology. Affected orchards usually have low disease incidence, and symptomatic plants are randomly to patchily distributed in ways that have not suggested any association to particular vector habits (A. H. Purcell, personal observations). Almond orchards adjacent to grape vineyards with PD usually do not have ALS. Also, almond orchards with ALS often occur adjacent to healthy vineyards (19).

When mechanically inoculated into grape, strains of $X$. fastidiosa from ALS caused PD, and vice versa (5). Grape strains of $X$. fastidiosa have a very wide range of hosts, mostly symptomless $(6,11,13,23)$. Hendson et al. (8) made molecular genetic comparisons of $X$. fastidiosa strains cultured from various plants, emphasizing grape and almond strains. They found that most almond strains formed two groupings (clusters) separate from a grouping of grape strains. Some almond strains fell within the grape cluster, but no grape strains grouped within either almond cluster, suggesting that grape strains are monophyletic but almond strains are not. Cross-inoculation experiments have been performed with only a few strains (5); thus, differences in host specificity with larger number of $X$. fas- tidiosa strains from grape and almond must be tested to determine host range, because most almond strains are clearly within different phylogenetic groups than grape strains.

New interest in ALS has emerged after the introduction of the sharpshooter Homalodisca coagulata (Say) (Hemiptera, Cicadellidae) into southern California in 1989 (25) and, more recently, into Kern County in 1998, at the southern end of California's Central Valley. This insect already has caused major economic losses by transmitting $X$. fastidiosa to grapevines in the Temecula Valley $(4,24)$, in Western Riverside County, CA, and today threatens vineyards and almond orchards in other areas of the state. Although just recently observed in almond orchards (in 2001-02), this new vector may increase the incidence of ALS because, unlike other sharpshooters associated with $X$. fastidiosa diseases in California, it appears to feed regularly on almond, with a distinct preference for woody shoots. The sharpshooter might transmit $X$. fastidiosa from infected vineyards and alfalfa fields to almond orchards, as well as to and from other hosts of the pathogen. This dissemination of strains that previously were limited to certain plants due to the host plant preference of native vectors may increase because of the large host range of $H$. coagulata (26). This might have devastating consequences to California's agriculture, such as the emergence of new $X$. fastidiosa diseases.

The objectives of our studies were to determine how efficiently $H$. coagulata could transmit $X$. fastidiosa to and from almond, whether this vector could inoculate woody shoots as well as green shoots and dormant plants in the laboratory, and if the same insect group could acquire two grape $X$. fastidiosa strains from grape and inoculate them into grape and almond. We also estimated the population densities of viable (cultivable) cells of $X$. fastidiosa in almond from ALS-symptomatic trees from several regions of California and almond plants maintained in the greenhouse, to test a hypothesis that the low transmission efficiencies we observed might have been due to low populations of $X$. fastidiosa in almond.

\section{MATERIALS AND METHODS}

Insects, bacteria, and plants. $H$. coagulata adults were used for all transmis- 
sion experiments. Insects were collected in citrus orchards at Bakersfield (Kern County, CA) or reared in the greenhouse from egg masses laid by field-collected adults. Insects were kept in plastic cages feeding on grape (Vitis vinifera), mugwort (Artemisia douglasiana), basil (Ocimum basilicum), and okra (Abelmoschus esculentus) as previously described (3). X. fastidiosa strains used in experiments were cultured from natural infections occurring in almond (strain Tulare, from Tulare County) and grape (strains STL [ATCC 700963] and Bakersfield, from Napa and Kern Counties, respectively; maintained by A. H. Purcell at the University of California, Berkeley); strains were stored at $-70^{\circ} \mathrm{C}$ until use. All strains were pathogenic to almond and grape after mechanical inoculation (11) in the greenhouse (data not shown). Briefly, we placed a 5- $\mu \mathrm{l}$ drop of an $X$. fastidiosa suspension with approximately $10^{9} \mathrm{CFU} / \mathrm{ml}$ on the stem of the plant, and pricked through it five times with a \#0 entomological pin. Plants of the susceptible almond cv. Peerless grafted on the peach rootstock Nemaguard were used for comparison of transmission to woody versus shoot tissues, to determine if two different grape strains were transmissible from grape to almond and grape, and for inoculation into dormant plants. We used seedlings of Peerless in experiments to determine the effect of time on acquisition and inoculation efficiency. Grapevines used were seedlings of the $X$. fastidiosasusceptible cvs. Cabernet sauvignon and Pinot noir. All insects and plants were kept in a greenhouse, where transmission experiments were conducted with temperatures maintained at approximately $25^{\circ} \mathrm{C}$.

$X$. fastidiosa culture and detection. We used culturing as a detection method (10) because it confirms the presence of live $X$. fastidiosa in plants. Briefly, petioles of symptomatic samples were surface sterilized, cut into small pieces, and aseptically ground with a tissue homogenizer (Polytron homogenizer; Brinkman Instruments, Inc., Westbury, NY) with a PT-10S generator probe. We plated 100-fold dilutions of the suspension onto modified periwinklewilt solid medium (PWG) (10) and incubated plates at $28^{\circ} \mathrm{C}$ for 7 to 14 days. The number of CFU per gram of petiole tissue was estimated by averaging the number of colonies observed in two $20-\mu$ d drops of the diluted ground suspension plated on PWG. The theoretical detection threshold for this method was $1 \times 10^{3} \mathrm{CFU} / \mathrm{g}$ of plant tissue, as previously described (10). Samples were processed immediately if collected from the greenhouse, or within $24 \mathrm{~h}$ if field collected. Randomly selected colonies were tested by polymerase chain reaction (PCR) with $X$. fastidiosa-specific primers at various times (16), and always identified as X. fastidiosa.

$H$. coagulata transmission experiments. Insects had access to entire source plants (X. fastidiosa-infected plants) during all acquisition access periods (AAPs). Leaf scorch symptoms were apparent on an estimated 50 to $90 \%$ of leaves on all source plants (17). For inoculation access periods (IAPs) on pretest and test plants, we confined insects to sections of almond plants and grapevines with mesh voile cages. All repetitions of various experiments had negative control plants (almond and grape) that were not exposed to insects. No negative controls developed symptoms or were $X$. fastidiosa-positive by culturing. All plants were kept in a greenhouse free of insects prior to transmission experiments.

To test the effect of time on acquisition efficiency, $H$. coagulata adults were pretested on healthy grape for 4 days prior to 1-, 2-, or 4-day AAPs on an almond source plant (Tulare strain). No pretested plants became infected with $X$. fastidiosa using the 4-day pretest period; thus, we considered these insects $X$. fastidiosa-free. After the AAP on source plants, we transferred single $H$. coagulata adults to healthy almond seedlings for a 4-day IAP, after which the plants were kept for later diagnoses. Thirty individuals were tested per AAP.

For studies on the effect of time on inoculation efficiency, insects had a 4-day AAP on symptomatic almond plants (Tulare strain), after which groups of four individuals were transferred for 1,2 , and 4 days to healthy almond seedlings. The same insect group was placed on three test plants consecutively, one for each period. The infective insects were divided into three cohorts (distinct groups with the same history), so that each cohort randomly started the experiment with a different IAP. The order of the subsequent IAPs also was mixed among cohorts to reduce the effect of varying environmental conditions on results. We used groups to inoculate plants to increase the chances of transmission to individual plants because preliminary data suggested that transmission efficiency per individual per day was low (24). We inoculated 50 plants per period. The linear regression between transmission and plant access period was calculated with Microsoft Excel 2002 (Microsoft Corporation, Redmond, WA).

We tested the ability of $H$. coagulata to inoculate 1-year-old woody tissues of almond plants as well as green shoots. We caged adult sharpshooters on grapevines infected with $X$. fastidiosa (STL strain) for 4 days. We confined groups of four $H$. coagulata for a 4-day IAP on woody tissues or green shoots of almond (grafted). After this IAP, we transferred groups feeding on 1-year-old wood (mature bark) for a 4-day IAP on shoots and those on shoots to 1-year-old wood. We inoculated 30 plants on each type of tissue. Transmission frequencies to shoots and woody tissue were compared by $\chi^{2}$ test using the Yates correction for continuity (1).

We conducted experiments to compare transmission of $X$. fastidiosa by the same group of insects to almond plants and grapevines. We pretested $H$. coagulata adults on healthy grape seedlings for 4 days. All pretest plants proved negative for $X$. fastidiosa by culturing 10 weeks or more after inoculation. After the pretest, we transferred the insects for a 4-day AAP on strains STL or Bakersfield in grape source plants. We then caged these insects on grape plants for a 4-day IAP in groups of four, followed by a 4-day IAP on almond. Experiments with different strains were conducted a week apart. Seven groups of four $H$. coagulata adults were tested per strain per host plant.

Transmission to dormant almond plants. In October 2000, grafted almond plants in 1-gallon pots prior to leaf abscission were taken outdoors at Berkeley to a screened outdoor cage. These plants lost their leaves naturally, were pruned, and, in January of 2001, were transferred to a cold box at $4{ }^{\circ} \mathrm{C}$ to prevent shoot cell division or elongation (dormant state). Buds began to swell and young leaves emerged approximately 1 week after we took a sample of two plants out of the cold box and kept them in a greenhouse. We tested if $\mathrm{H}$. coagulata could survive on these dormant vines 1 day after the plants were brought in from the cold box. In a preliminary trial, insects survived and fed (determined by observation of excretion) on these plants for 4 days. Therefore, we started our IAP on dormant plants 1 day after the almond plants were brought into the greenhouse from $4^{\circ} \mathrm{C}$. As is true of grapevines under the same conditions, no almond plants exhibited positive root pressure (exudate through wound) after pricking stems with an entomological needle (\#0), up to resumption of bud swell (data not shown). Thus, we relied on $H$. coagulata feeding as sufficient evidence to show that at least some xylem elements were filled by root pressure or differentiation of cambium initials. Transmission experiments occurred from January to March 2001. We combined insects for a 4-day AAP on grape source plants (Tulare strain) maintained in the greenhouse during the winter and then transferred them for a 4-day IAP on growing grape seedlings maintained in the greenhouse. This allowed us to retrospectively estimate which $H$. coagulata groups (four individuals per group) were infective. We transferred all groups to dormant test plants for three successive 4day IAPs (each IAP on a different dormant almond) in a growth chamber (14:10 photoperiod, soil and air temperature at $17^{\circ} \mathrm{C}$ ). After the IAP, plants were maintained in the greenhouse for symptom development.

Survey of bacterial populations. We quantified live $X$. fastidiosa populations from experimental and naturally occurring infections in California orchards by the culture method as described above. From a total of eight plants, 25 branches with ALS-symptomatic leaves in an orchard at Davis, CA (University of California at 
Davis, Armstrong Orchard) were inoculated in 1997 with various strains (8) of $X$. fastidiosa for other field experiments (unpublished data). Symptomatic branches were retagged in 1999, and samples taken and processed in April, June, and September 2001. Because of the low number of positive samples in 2001 and the spread of the pathogen to other (untagged) symptomatic branches within the same trees, we tagged branches again in 2001. We took samples from these branches in the same three months in 2002. We also collected symptomatic leaves from needle-inoculated plants kept in the greenhouse (Tulare strain), and from trees with ALS occurring in commercial orchards in Stanislaus and Kern counties in 2001 and 2002.

\section{RESULTS}

H. coagulata transmission experiments. Out of 30 almond plants tested, 3, 2 , and 1 became infected for 1-, 2-, and 4day AAPs by individual insects, respectively (average of $6.7 \%$ transmission per plant). No insects died during the IAP on the test plants. Inoculation efficiency by group increased with time, but the estimated transmission per individual per day (20) remained constant, at about $4 \%$ (Fig. 1). H. coagulata groups that transmitted $X$. fastidiosa after a 1- or 2-day IAP also transmitted after a 4-day IAP (except one group that transmitted only at a 2-day IAP); nine groups transmitted only with a 4-day IAP. Survival of $H$. coagulata on almond plants was high; only 6 of 194 insects died during the IAP experiments (total of 7 days with subsequent IAP).

$H$. coagulata fed on and inoculated $X$. fastidiosa into 1-year-old woody tissues of almond. All groups that transmitted the bacterium to woody stems (37\%) also transmitted to young green shoots; five groups $(16 \%)$ inoculated only shoots. Of 30 groups, $16(53 \%)$ transmitted to green shoots, which was not significantly different from the 11 groups that also transmitted to 1-year-old wood $\left(\chi^{2}\right.$ test with Yates correction factor for continuity, $P=0.29,1$ df). There were no significant differences in $H$. coagulata survival rates; an average of 3.87 insects per plant survived the 4-day IAP on both types of tissues.

$H$. coagulata acquired the STL and Bakersfield strains from grape sources, and inoculated both strains into grape and almond test plants. After acquisition by $H$. coagulata from grape infected with STL, subsequent inoculation caused 6 of 7 grape plants to become symptomatic with PD and 3 of 7 almond plants with ALS. When insects acquired the Bakersfield strain from grape, 2 of 7 groups transmitted to grape, but 5 of 7 transmitted to almond. Overall, 6 of 28 insects died during the 4-day IAP on grape and another 4 died during the 4-day IAP on almond.

Transmission to dormant almond plants. A total of 15 groups of $4 \mathrm{H}$. co- agulata were tested in three repetitions of the experiment. Nine of these groups transmitted to pretest grape; none of the remaining six groups transmitted to dormant almond. The nine infective groups fed on 27 dormant almond plants, of which 9 became infected with $X$. fastidiosa (detection by culture) and showed typical ALS symptoms. Survival of $H$. coagulata on pretest grapevines and dormant almond plants was high at 93.3 and $99.4 \%$, respectively.

Survey of bacterial populations. At the Davis site, leaves were not yet full size when collected in April. When we collected samples in June, we observed initial foliar symptoms of marginal leaf necrosis precluded by a narrow band of chlorotic tissue. Bacterial populations and the number of positive samples were greater than in the April samples (Table 1). All samples collected in September 2002 were symptomatic and positive for $X$. fastidiosa. $X$. fastidiosa populations found within the petiole of symptomatic leaves collected in Modesto in 2001 were similar to those obtained at Davis in 2002 during the same period of the year (September; Table 2).
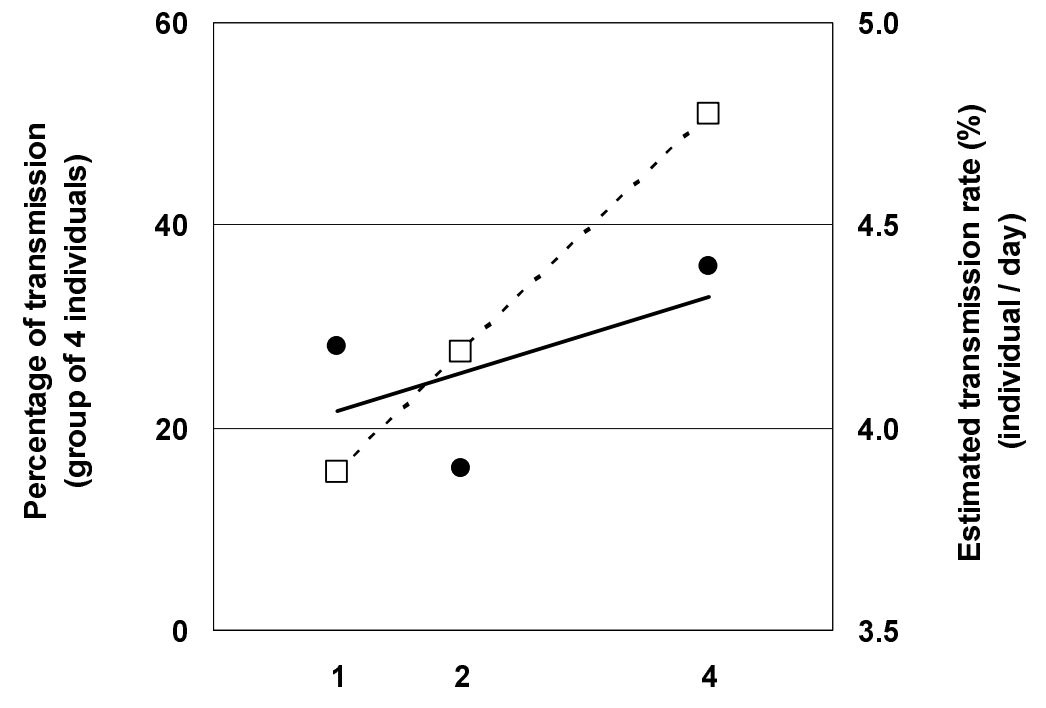

\section{Inoculation access period (days)}

Fig. 1. Homalodisca coagulata transmission of Xylella fastidiosa to almond after a 4-day acquisition access period on almond source plants, followed by various inoculation access periods on healthy almond plants. Open squares represent inoculation rates by groups of four insects caged per plant; dashed line is the regression for those data points (transmission probability $y=3.922+11.765$ access time $\left.x, r^{2}=1, P<0.001\right)$. Solid circles represent the calculated transmission rates per individual per day (20); solid line is the regression (not significant; $P=0.62$ ) for those points.

Table 1. Populations of Xylella fastidiosa within petioles of plants with almond leaf scorch symptomatic leaves from Davis, $\mathrm{CA}^{\mathrm{a}}$

\begin{tabular}{|c|c|c|c|c|c|c|}
\hline \multirow[b]{3}{*}{ Samples } & \multicolumn{2}{|c|}{ April } & \multicolumn{2}{|c|}{ June } & \multicolumn{2}{|c|}{ September } \\
\hline & 26 & 28 & 14 & 20 & 26 & 16 \\
\hline & 2001 & 2002 & 2001 & 2002 & 2001 & 2002 \\
\hline Number tested & 18 & 25 & 21 & 25 & 24 & 17 \\
\hline Number positive & 2 & 3 & 4 & 18 & 4 & 17 \\
\hline Median (CFU/g of tissue) & $3.5 \times 10^{5}$ & $2.1 \times 10^{4}$ & $2.5 \times 10^{5}$ & $1.5 \times 10^{6}$ & $1.2 \times 10^{6}$ & $1.5 \times 10^{7}$ \\
\hline
\end{tabular}

${ }^{a}$ Measured on given dates within month and year indicated. 
Table 2. Populations of Xylella fastidiosa within petioles of plants with almond leaf scorch symptomatic leaves from various locations in California

\begin{tabular}{|c|c|c|c|c|}
\hline Location & Collection date & $n^{\mathbf{a}}$ & Median $^{b}$ & Range \\
\hline Modesto (Stanislaus County) & July 2001 & 28 & $1.2 \times 10^{6}$ & $8.3 \times 10^{3}-6.2 \times 10^{7}$ \\
\hline Denair (Stanislaus County) & August 2002 & 24 & $3.5 \times 10^{6}$ & $1.3 \times 10^{5}-1.3 \times 10^{7}$ \\
\hline Modesto (Stanislaus County) & August 2002 & 24 & $1.3 \times 10^{7}$ & $5.0 \times 10^{5}-4.0 \times 10^{7}$ \\
\hline Ceres (Stanislaus County) & August 2002 & 24 & $2.0 \times 10^{7}$ & $3.2 \times 10^{6}-5.1 \times 10^{7}$ \\
\hline Bakersfield (Kern County) & September 2002 & 10 & $2.6 \times 10^{7}$ & $1.2 \times 10^{7}-6.3 \times 10^{7}$ \\
\hline Waterford (Stanislaus County) & August 2002 & 24 & $2.7 \times 10^{7}$ & $5.9 \times 10^{6}-9.5 \times 10^{7}$ \\
\hline Greenhouse-Berkeley & September 2002 & 22 & $5.4 \times 10^{7}$ & $2.5 \times 10^{7}-8.0 \times 10^{7}$ \\
\hline
\end{tabular}

a Number of samples tested.

b CFU/g of tissue.

transmission efficiency by vectors has been correlated previously with bacterial populations within grape (12). The low acquisition efficiency that we observed for $H$. coagulata on almond, associated with the low bacterial populations found within this host, suggest that a similar situation may occur with ALS dissemination by vectors. In this study, transmission efficiency apparently was limited by acquisition efficiency. Increasing AAPs from 1 to 4 days did not increase transmission, but longer IAPs resulted in higher transmission rates (per insect group). On grapevines, $\mathrm{H}$. coagulata's acquisition efficiency was maximized by 1 day, whereas transmission increased with longer IAPs (3), as observed in this study with almond. The observation that $H$. coagulata's acquisition efficiency did not increase with longer AAPs on almond and grape deserves further investigation.

Inoculations of woody tissues at any time, especially during the dormant season, may generate infections in older tissues that might make ALS control by pruning a challenging effort. We do not know if $H$. coagulata feeds in almond orchards during the winter, as it has been observed to do on grape (14). Possible transmission of $X$. fastidiosa to almond plants during dormancy could expand the period requiring vector control. $X$. fastidiosa transmission to plants assumed to have positive root pressure (dormant plants) suggests that vector transmission of $X$. fastidiosa to plants does not require negative xylem tension to introduce the bacterium into the host.

The prospect for ALS epidemiology with $H$. coagulata may differ markedly from that of PD (21), but has various similarities with citrus variegated chlorosis (CVC) in Brazil (15). X. fastidiosa populations that we observed in almond and those reported from citrus (2) were both low compared with grape (11). Differences obtained among tested areas may be related to $X$. fastidiosa strain, almond cultivar, location, soil conditions, and orchard management, all variables which have not been considered in this survey. Recent evidence from bacterial counts using quantitative PCR in CVC (18) suggests that the low number of detectable CFU (at least within citrus) is similar to the total number of cells within the plant, and that most of those bacteria are cultivable (2). We do not know why $X$. fastidiosa-infected almond and citrus have lower CFU counts than grape, although we believe it may be associated at least in part with length and diameter of individual xylem vessels. In both ALS and CVC, symptoms initially are limited to sections of plants, and years are required for infection to expand throughout the entire plant. The major difference from ALS in California is that CVC has a wider range of vector species, both herb- and tree-feeders (15), whereas an important vector has not been identified for ALS thus far (19). The lack of constant vector pressure may be the reason why ALS is not an important disease of almond in California. This situation may change for areas with a significant population of $H$. coagulata. To our knowledge, studies to analyze temporal and spatial distributions of this vector in almond orchards or its relation to ALS incidence have only just begun.

The low bacterial populations within almond petioles during the spring suggest that almond-to-almond spread of $X$. fastidiosa may not be a major factor for increases in disease incidence during spring, but vector acquisition of $X$. fastidiosa from dormant almond plants should be determined. On the other hand, after midsummer, tree-to-tree spread may become important, because bacterial numbers are higher and the first generation of $H$. coagulata adults is at its highest numbers (4). These conditions indicate that, during the spring, controlling the migration of infective vectors from adjacent vineyards and alfalfa fields into almond orchards might reduce ALS spread. However, during the summer and fall, control at borders and within orchards may be desirable, depending on disease incidence within the orchard.

Because of the low transmission efficiency by $H$. coagulata from almond to almond, X. fastidiosa spread within orchards might be controlled efficiently by reducing vector numbers and eliminating ALS-diseased trees (20). Pruning of branches showing incipient symptoms has been suggested to be a potential strategy to control the disease (S. M. Mircetich and G. Nyland, Compendium of Research Projects 1972-1998, Almond Board of California, Modesto, CA). The control strategies proposed for ALS, based on current knowl- edge of the disease, are very similar to those currently used in Brazil to control CVC: reducing vector numbers and pruning of symptomatic branches (15).

\section{ACKNOWLEDGMENTS}

R. Almeida had a scholarship from 'Conselho Nacional de Desenvolvimento Científico e Tecnológico' (Brasília, Brazil). This work is part of R. Almeida's Ph.D. dissertation at the University of California at Berkeley. We thank E. Norberg for technical assistance with greenhouse experiments; B. Holtz, R. Duncan (University of California Cooperative Extension), and B. Higbee (Paramount Farming Company) for assistance with field collected samples; C. Montllor, E. Norberg, and $\mathrm{T}$. Wistrom for discussions and revision of the manuscript; and The Duarte Nursery (Modesto, CA) for kindly donating the grafted almond plants used here.

\section{LITERATURE CITED}

1. Agresti, A., and Finlay, B. 1997. Statistical Methods for the Social Sciences. 3rd ed. Prentice-Hall Inc., Upper Saddle River, NJ.

2. Almeida, R. P. P., Pereira, E. F., Purcell, A. H., and Lopes, J. R. S. 2001. Multiplication and movement of a citrus strain of Xylella fastidiosa within sweet orange. Plant Dis. 85:382-386.

3. Almeida, R. P. P., and Purcell, A. H. Transmission of Xylella fastidiosa to grapevines by Homalodisca coagulata (Hemiptera, $\mathrm{Ci}$ cadellidae). J. Econ. Entomol. 96:264-271.

4. Blua, M. J., Phillips, P. A., and Redak, R. A. 1999. A new sharpshooter threatens both crops and ornamentals. Calif. Agric. 53:2225.

5. Davis, M. J., Thomson, S. V., and Purcell, A. H. 1980. Etiological role of a xylem-limited bacterium causing Pierce's disease in almond leaf scorch. Phytopathology 70:472-475.

6. Freitag, J. H. 1951. Host range of Pierce's disease virus of grapes as determined by insect transmission. Phytopathology 41:920934.

7. Gupta, A. K., and Sharma, R. C. 1998. Almond leaf scorch - a serious threat to almond cultivation in Himachal Pradesh. Indian Phytopathol. 51:203.

8. Hendson, M., Purcell, A. H., Chen, D., Smart, C., Guilhabert, M., and Kirkpatrick, B. C. 2001. Genetic diversity of Pierce's disease strains and other pathotypes of Xylella fastidiosa. Appl. Environ. Microbiol. 67:895903.

9. Hewitt, W. B., Houston, B. R., Frazier, N. W. and Freitag, J. H. 1946. Leafhopper transmission of the virus causing Pierce's disease of grape and dwarf of alfalfa. Phytopathology $36: 117-128$.

10. Hill, B. L., and Purcell, A. H. 1995. Acquisition and retention of Xylella fastidiosa by an efficient vector, Graphocephala atropunctata. Phytopathology 85:209-212.

11. Hill, B. L., and Purcell, A. H. 1995. Multiplication and movement of Xylella fastidiosa 
within grapevine and four other plants. Phytopathology 85:1368-1372.

12. Hill, B. L., and Purcell, A. H. 1997. Populations of Xylella fastidiosa in plants required for transmission by an efficient vector. Phytopathology 87:1197-1201.

13. Hopkins, D. L., and Adlerz, W. C. 1988. Natural hosts of Xylella fastidiosa in Florida. Plant Dis. 72:429-431.

14. Hopkins, D. L., and Purcell, A. H. 2002. Xylella fastidiosa: cause of Pierce's disease of grapevine and other emergent diseases. Plant Dis. 86:1056-1066.

15. Lopes, J. R. S. 1999. Estudos com vetores de Xylella fastidiosa e implicações no manejo da clorose variegada dos citros. Laranja 20:329-344.

16. Minsavage, G. V., Thompson, C. M., Hopkins, D. L., Leite, R. M. V. B. C., and Stall, R. E. 1994. Development of a polymerase chain reaction protocol for detection of Xylella fas- tidiosa in plant tissue. Phytopathology 84:456-461.

17. Moller, W. J., Sanborn, R. R., Mircetich, S M., Williams, H. E., and Beutel, J. A. 1974. A newly recognized and serious leaf scorch disease of almond. Plant Dis. Rep. 58:99-101.

18. Oliveira, A. C., Vallim, M. A., Semighini, C. P., Araujo, W. L., Goldman, G. H., and Machado, M. A. 2002. Quantification of $X y$ lella fastidiosa from citrus trees by real-time polymerase chain reaction assay. Phytopathology 92:1048-1054.

19. Purcell, A. H. 1980. Almond leaf scorch: leafhopper and spittlebug vectors. J. Econ. Entomol. 73:834-838.

20. Purcell, A. H. 1981. Vector preference and inoculation efficiency as components of resistance to Pierce's disease in European grape cultivars. Phytopathology 71:429-435.

21. Purcell, A. H., and Feil, H. 2001. Glassy- winged sharpshooter. Pestic. Outlook 12:199. 203.

22. Purcell, A. H., and Hopkins, D. L. 1996. Fastidious xylem-limited bacterial plant pathogens. Annu. Rev. Phytopathol. 34:131-151.

23. Purcell, A. H., and Saunders, S. R. 1999. Fate of Pierce's disease strains of Xylella fastidiosa in common riparian plants in California. Plant Dis. 83:825-830.

24. Purcell, A. H., and Saunders, S. R. 1999. Glassy-winged sharpshooters expected to increase plant disease. Calif. Agric. 53:26-27.

25. Sorensen, J. T., and Gill, R. J. 1996. A range extension of Homalodisca coagulata (Say) (Hemiptera: Clypeorrhyncha: Cicadellidae) to southern California. Pan-Pac. Entomol. 72:160-161.

26. Turner, W. F., and Pollard, H. N. 1959. Insect transmission of phony peach disease. U. S. Dep. Agric. Tech. Bull. 1193. 